\title{
The association between personal history and the outcomes of transobturator sling surgery
}

\author{
(iD) Paula da Silva Feitosa ${ }^{1}$ \\ (Dicolle Henriques Barreto Colaço' \\ (iD) Cristiane Regina Barros ${ }^{2}$ \\ (iD) Thomaz Rafael Gollop 3 \\ (iD) Ana Carolina Marchesini ${ }^{4}$
}

\begin{abstract}
1. Undergraduate students of the fourth year of the medical program of the Jundiaí Medical Faculty; Jundiaí, SP, Brasil 2. Graduate in physical therapy and masters student at the Jundiaí Medical Faculty; Jundiaí, SP, Brasil 3. Associate professor of the gynecology course of the obstetrics and gynecology department of the Jundiaí Medical Faculty; Jundiaí, SP, Brasil 4. Adjunct professor of the gynecology course of the obstetrics and gynecology department of the Jundiaí Medical Faculty; Jundiaí, SP, Brasil Study conducted at the University Hospital of the Jundiai Medical Faculty
\end{abstract}

http://dx.doi.org/10.1590/1806-9282.65.6.864

\section{SUMMARY}

OBJECTIVE: This study aims to verify the association between risk factors for the onset of SUI and transobturator suburethral sling surgical treatment outcomes.

PATIENTS AND METHODS: A retrospective study was conducted with 57 patients operated by the Pelvic Floor Surgery Service. Demographic data were compiled from the sample, the body mass index (BMI) was calculated, and the patients were divided according to the response to the surgical treatment.

RESULTS: A total of 77.2\% of the sample was cured or improved after surgical treatment. Out of the total sample, $75.4 \%$ of the women were postmenopausal, and $73.7 \%$ denied current or past smoking. The median age was 61 years, the median number of births was 4.0, the median BMI was $28.6 \mathrm{~kg} / \mathrm{m} 2$, and $50.9 \%$ of the sample was classified as pre-obese. BMI, menopausal status, age, smoking, and sexual activity were not factors associated with the surgical outcome. However, parity equal to or greater than 5 was associated with worse postoperative results $(p=0.004)$.

CONCLUSIONS: among risk factors associated with the emergence of SUI, only parity greater than 4 showed a negative impact on transobturator sling surgery outcomes.

KEYWORDS: Urinary incontinence. Obesity. Parity. Menopause. Suburethral slings.

\section{INTRODUCTION}

Urinary incontinence (UI) is defined by the International Continence Society as any unintentional leakage of urine'. The onset of this disease is associated with risk factors such as high parity, the hormonal environment of hypoestrogenism of menopause, neurological diseases, metabolic diseases, the use of diuretic medication, a history of pelvic surgeries, and situations of chronic increase of intra-abdominal pressure $^{2}$. The prevalence of UI is highly variable, depending on the age range of the population studied, with higher frequency in women and, among these, those who declared themselves as from a non-white ethnic group, with more advanced age, and with lower levels of formal education ${ }^{2}$. It is a condition that causes significant social stigma and can encumber the public and complementary health systems ${ }^{3}$. 
The most frequent type is the stress urinary incontinence(SUI), characterized by the involuntary leakage of urine associated to physical exertion when the intravesical pressure exceeds the urethral pressure due to a failure in the urethral resistance mechanisms ${ }^{2}$. Its treatment can be conservative or with physical therapy, but when these fail or if there is a worsening of the condition, surgical treatment is indicated. According to a SUS - Datasus report on hospital procedures, in 2007, 8,617 surgical procedures for correction of urinary incontinence in women were performed, totaling an expense of $\mathrm{R} \$ 2.95$ million$^{2}$.

The surgical treatment is currently based on the placement of synthetic strips called slings in the suburethral topography, and the pubic-vaginal ones in the retropubic space are the most used ${ }^{4}$. More recently, suburethral slings have been positioned using the transobturator approach with similar results. The success rates of sling surgeries vary from $74 \%$ to $95 \%$ with published follow-up of up to 17 years, including cases of SUI (bladder neck hypermobility and recurrent cases) and mixed urinary incontinence (MUI) due to sphincteric deficiency ${ }^{5}$.

The onset of SUI is related to risk factors for increased intra-abdominal pressure and pelvic floor disorders $^{2}$. However, little is known on the influence of these same factors in the success of the surgical treatment of the disease. Therefore, the present study aims to verify the association of risk factors linked with the onset of SUI with the results of surgical treatment with the outcomes of transobturator sling surgery, according to the patient's own assessment in relation to their urinary leakage. Specifically, factors such as BMI, parity, menopausal status, age, and smoking will be verified as influencers of therapeutic success.

\section{METHODS}

A retrospective study was conducted with a convenience sample using the cases operated by the Pelvic Floor Department of the Gynecology Course - Medical Faculty of Jundiaí (FMJ). The study was approved by the Research Ethics Committee (CAAE - 45104915.1.0000.5412). We selected the patients operated for SUI treatment between 2012 and 2016. The transobturator sling surgeries were always performed by the same two team members and 1-cm-wide polyvinylidene meshes, pre-cut, by Dynamesh-SIS (BMR - Medical) were used. All surger- ies were performed following an inpatient regimen with discharge after 24 hours of the procedure. In relation to the surgical technique, the patients were submitted to spinal anesthesia, and on lithotomy position the middle urethra was identified; saline solution was infused in the suburethral anterior vaginal mucosa for hydrodissection; then, an incision of approximately $2 \mathrm{~cm}$ was made on the mucosa at the middle third of the urethra, where the sling was then placed using the inside-out technique with the aid of the passage of transobturator needles.

The data from the medical records regarding age, weight, height, parity, types of childbirth, menopausal status, smoking, sexual activity, and symptoms of urinary incontinence before and after surgical treatment were compiled. The data were then stored in an Excel $^{\circledR}$ spreadsheet database for subsequent statistical analysis. With the height and weight data of patients, we calculated the BMI (body mass index) using the following formula: $\mathrm{BMI}=$ weight $(\mathrm{kg}) /$ height $\mathrm{x}$ height $\left(\mathrm{m}^{2}\right)$. According to the World Health Organization (WHO), women were classified as follows, based on their BMI: underweight $<18.5 \mathrm{~kg} / \mathrm{m}^{2}$; normal weight $18.5<24.9$ $\mathrm{kg} / \mathrm{m}^{2}$; overweight $>25-29.9 \mathrm{~kg} / \mathrm{m}^{2}$; and obese $>30 \mathrm{~kg} /$ $\mathrm{m}^{2}$. The age was expressed in complete years, disregarding the months. The presence of sexual activity was recorded as yes or not. The patients were classified according to their hormonal status into pre-menopausal and post-menopausal; women with absent menstruation for 12 months or more were placed in the post-menopausal group. Smoking was noted as "yes" if present, "no" if the patient had never smoked, or "former smoker" if the patients reported having stopped smoking for at least 12 months. In relation to smoking, the current smokers were studied in along with the former smokers.

In relation to the response to surgical treatment, the patients were divided into: "cured SUI", if they did not present any more episodes of leakage after the surgery; "improved SUI" if they presented a reduced number of urinary leakage after the surgery and did not require any other surgical or conservative intervention; "no SUI improvement", when there was no reduction in the number of urinary leakages after the surgery; and "new urgency symptoms" if they started having incontinence episodes, based on the self-reporting of the patients and notes on the medical records. Due to the sample size, the cases were grouped into "cured SUI" and "improved SUI" when the surgical outcomes were satisfactory, and "no improvement of 
SUI" and "new urgency symptoms" when the surgical outcomes were unsatisfactory.

The data obtained were submitted to a descriptive analysis in which the general frequencies were classified (in a univariate table), followed by a bivariate analysis, in which the Yates chi-square test and the Fisher exact test were used to test the association of therapeutic success (cure of SUI or not) against the independent variables. Finally, using the forward selection method, the multivariate analysis was performed using a logistic regression model, considering six independent variables, with the last four being dichotomized (age, BMI, parity, menopausal status, smoking, and sexual activity). We pre-set alpha at $5 \%$, and the software used was SPSS version $13^{\circledR}$.

\section{RESULTS}

We analyzed a total of 63 patients, of which eight were excluded because they did not fulfill all the criteria of inclusion (flowchart). The age range found for the 55 patients included in this study was 34 to 88 years, with an average of 61.3 years $(\mathrm{SD} \pm 12.5)$ and a median age of 61 years. In relation to the number of births, the average was 4.5 ( \pm 2.6 births SD), the median of births was 4.0 , with a minimum of 1 birth and a maximum of 13 births. After the calculations of

TABLE 1.

\begin{tabular}{l|l|l|l} 
Variable/postoperative result & N & $\%$ \\
\hline \multirow{4}{*}{ BMI } & Normal & 9 & 15.8 \\
\cline { 2 - 4 } & Pre-obese & 29 & 50.9 \\
\cline { 2 - 4 } & Obesity grade 1 & 14 & 24.6 \\
\cline { 2 - 4 } & Obesity grade 2 & 3 & 5.3 \\
\cline { 2 - 4 } & Obesity grade 3 & 2 & 3.5 \\
\hline \multirow{4}{*}{ Hormonal status } & Menopausal & 43 & 75.4 \\
\cline { 2 - 4 } & Pre-menopausal & 11 & 19.3 \\
\cline { 2 - 4 } & Not informed & 3 & 5.3 \\
\hline \multirow{5}{*}{ Smoker } & No & 42 & 73.7 \\
\cline { 2 - 4 } & Former smoker & 5 & 8.8 \\
\cline { 2 - 4 } & Yes & 8 & 14.0 \\
\cline { 2 - 4 } & Not informed & 2 & 3.5 \\
\hline \multirow{5}{*}{ Sexual activity } & Present & 27 & 47.4 \\
\cline { 2 - 4 } & Absent & 23 & 40.4 \\
\cline { 2 - 4 } & Not informed & 7 & 12.3 \\
\hline \multirow{4}{*}{\begin{tabular}{l} 
SUI postatus \\
\cline { 2 - 4 }
\end{tabular}} & Cured & 29 & 50.9 \\
\cline { 2 - 4 } & Improved & 15 & 26.3 \\
\cline { 2 - 4 } & No improvement & 10 & 17.5 \\
\cline { 2 - 4 } & New urgency symptoms & 1 & 1.8 \\
\cline { 2 - 4 } & Not informed & 2 & 3.5 \\
\hline
\end{tabular}

BMI, we obtained an average of $28.9 \mathrm{~kg} / \mathrm{m}^{2}(\mathrm{SD} \pm 4.6)$, a median of $28.6 \mathrm{~kg} / \mathrm{m}^{2}$ with a minimum of 18.8 and a maximum of $44.1 \mathrm{~kg} / \mathrm{m}^{2}$.

Half of the patients in the sample presented a BMI between 25.0 and $29.9 \mathrm{~kg} / \mathrm{m}^{2}$, being classified as pre-obese (50.9\%); only $15.8 \%$ of the patients had a healthy BMI, and $33.4 \%$ of the patients were obese. Most of the patients were on menopause (75.4\%) and had no current or past habit of smoking $(73.7 \%)$. In relation to the surgical outcomes, 29 (50.9\%) patients presented no more episodes of UI, 15 (26.3\%) patients reported improvement of UI after the surgery, 10 (17.5\%) patients showed no improvement and only one (1.8\%) developed symptoms of urgency (Table 1).

Due to the small number of patients with normal BMI, for statistical analysis purposes, the patients were grouped according to their BMI into "healthy + pre-obese" and compared to the patients with "obesity grades 1, 2 and 3" together. For the patients with healthy weight or pre-obese, surgery had satisfactory outcomes in $78.4 \%$, and in the obese group, the rate of cure or improvement was $83.3 \%$ (Table 2).

Regarding the correlation between surgical outcome and age, $81.5 \%$ of women up to 59 years old presented satisfactory surgical outcomes, as well as most patients (78.6\%) above 60 years old ( $p>0.999)$.

TABLE 2. BIVARIATE ANALYSIS OF THE THERAPEUTIC OUTCOME (POSTOPERATIVE) ACCORDING TO THE VARIABLES OF THE STUDY.

\begin{tabular}{|c|c|c|c|c|}
\hline & & \multicolumn{2}{|c|}{ SUI Postoperative } & \multirow[b]{2}{*}{$\mathrm{p}$} \\
\hline & & $\begin{array}{l}\text { Cured or } \\
\text { better } \\
\mathrm{N}(\%)\end{array}$ & $\begin{array}{l}\text { No improve- } \\
\text { ment or new } \\
\text { urgency symp- } \\
\text { toms } N(\%)\end{array}$ & \\
\hline \multirow[t]{2}{*}{ Age } & Up to 59 years & $22(81.5)$ & $5(18.5)$ & \multirow[t]{2}{*}{$>0.999^{*}$} \\
\hline & $\geq 60$ years & $22(78.6)$ & $6(21.4)$ & \\
\hline \multirow{2}{*}{$\begin{array}{l}\text { Hormonal } \\
\text { status }\end{array}$} & Menopause & $34(81.0)$ & $9(19.0)$ & \multirow[t]{2}{*}{$0.678^{* *}$} \\
\hline & $\begin{array}{l}\text { Pre-meno- } \\
\text { pause }\end{array}$ & $8(72.7)$ & $3(27.3)$ & \\
\hline \multirow[t]{2}{*}{ Parity } & $\leq 4$ & $30(93.8)$ & $2(6.3)$ & \multirow[t]{2}{*}{$0.004^{\star *}$} \\
\hline & 5 or $>$ & $13(59.1)$ & $9(40.9)$ & \\
\hline \multirow[t]{2}{*}{$\mathrm{BMI}$} & $\begin{array}{l}\text { Healthy or } \\
\text { pre-obese }\end{array}$ & $29(78.4)$ & $8(21.6)$ & \multirow[t]{2}{*}{$>0.999^{\star \star}$} \\
\hline & $\begin{array}{l}\text { Obesity grade } \\
1,2 \text {, and } 3\end{array}$ & $15(83.3)$ & $3(16.7)$ & \\
\hline \multirow[t]{2}{*}{ Smoker } & Never & 35 (85.4) & $6(14.6)$ & \multirow[t]{2}{*}{$0.109^{\star *}$} \\
\hline & $\begin{array}{l}\text { Yes or former } \\
\text { smoker }\end{array}$ & $8(61.5)$ & $5(38.5)$ & \\
\hline \multirow{2}{*}{$\begin{array}{l}\text { Sexual } \\
\text { activity }\end{array}$} & Present & $21(77.8)$ & $6(22.2)$ & \multirow[t]{2}{*}{$>0.999^{\star \star}$} \\
\hline & Absent & 17 (77.3) & $5(22.7)$ & \\
\hline
\end{tabular}

*Yates Chi-square test. ${ }^{\star *}$ Fisher Exact Test 
The menopausal status also did not influence the response to surgical treatment, since the rate of cure or improvement was $81 \%$ and $72.7 \%$ in menopausal and non-menopausal women, respectively $(p=0.678)$. The presence of sexual activity and the habit of smoking also showed a negative association with the response to surgical treatment, although the population of smokers and former smokers had a tendency for more cases of patients without improvement or with new symptoms of urgency (Table 2).

Considering a cut-off point for parity equal to 4 , since the median for parity was 4 , and the average was 4.5 births, we found that the UI cure or improvement rates were significantly higher in patients with four or fewer births in relation to patients with five or more births, $93.8 \%$ versus $59.1 \%$, respectively $(\mathrm{p}=0.004)$ (Table 2).

To control the confounding factors, parity remained as the only constant to increase the likelihood of developing comorbidities in the postoperative period ( $\mathrm{p}=0.009)$ (Table 3 ).

\section{DISCUSSION}

The onset of UI has well-documented risk factors, such as age, factors of increased intra-abdominal pressure (such as chronic cough and constipation), menopausal status, obesity, and multiparity, but the association of these risk factors with the outcomes of surgical treatment is still inconsistent in the literature $^{6-11}$. Advanced age has long been related to the development of $\mathrm{UI}^{6,7}$, likely because it is associated with comorbidities that are facilitators of urinary disorders, such as diabetes and neuropathies, but also due to the concomitance with hypoestrogenism and the use of diuretic medications for the control of hypertension and heart diseases. The average age of the patients included in this study was 61.3 years, which is a little higher than the average of 54.1 years described in another national study ${ }^{6}$ and similar to the average age described in other international studies. In our study, age did not influence the rates of satisfactory outcomes (cure or improvement in $81.5 \%$ $\mathrm{x} 78.6 \%$ of patients aged $<60$ years and $\geq 60$ years, respectively). The literature data suggest that, in fact, the influence of age on the outcome of the UI treatment is related to the fact that young women take more risks of undergoing invasive procedures, obtaining higher cure rates ${ }^{8}$.

The patient post-menopausal hormonal status has a great influence on the onset of UI, as well as other dysfunctions of the genital tract, such as vaginal atrophy and prolapse. The entire female genital tract has estrogen receptors that regulate the synthesis and the breakdown of collagen, in addition to increasing urethral resistance by stimulating increased periurethral vascularization (corresponding to $1 / 3$ of the urethral pressure); they also promote the relaxation of the detrusor muscle, reducing the frequency and amplitude of its contractions ${ }^{12-14}$. A case-control study conducted in Vienna with 94 patients found a higher risk of UI in the post-menopausal period and that the reduction, mainly of estradiol, is closely related to $\mathrm{SUI}^{15}$. In the present study, we also found that most patients operated were post-menopausal (75.4\%), but there was no association between menopausal status and the outcome of the surgical treatment since there was cure or improvement in $81 \%$ and $72.7 \%$ of the patients in post and pre-menopause, respectively. Up to this time, we did not find any data in the literature involving this kind of correlation.

It is believed that a higher BMI is associated with increased risk of urinary incontinence $e^{9,10,16}$ because the excess weight would increase intra-abdominal pressure, which would lead to the increase of vesical pressure, greater urethral mobility and, consequently, UI ${ }^{17}$. A study that included 82 women with UI who underwent bariatric surgery found an improvement of urinary complaints in $83 \%$ of the women after weight reduction, and 33\% reported cure of UI after bariatric surgery, validating the association between obesity and urinary leakage ${ }^{18}$.

Sling surgeries are recent. The technique was first described in 1907 by Giordano and performed in humans in 2001 by the French urologist Delorme. This "new" treatment has been gradually replacing the Burch technique, of 1961, with a similar cure rate and lower morbidity ${ }^{19}$. According to a study conducted with 514 SUI patients who underwent transobturator sling surgery, with a follow-up of at least six weeks, the rate of subsequent surgery for tape transection was $0.8 \%$. In the same study, the cure rate, after a follow-up of at least 12 months, was $84.2 \%^{20}$.

TABLE 3 - VARIABLE ASSOCIATED WITH COMORBIDITY.

\begin{tabular}{l|l|l|l} 
Variable & B & SE & P \\
\hline Parity & 2.238 & 0.857 & 0.009 \\
Constant & -2.526 & 0.735 & 0.001 \\
\hline${ }^{*}$ Multiple logistic regression model $(n=48)$. & \\
$B \rightarrow$ estimated coefficient \\
SE $\rightarrow$ standard error of the estimated coefficient
\end{tabular}


However, it is important to consider risk factors for failure of the sling surgery, like in the Burch technique, in which obesity has been proven to be a risk factor. A Brazilian study demonstrated that patients with BMI $>30$ have a 3.7 times greater likelihood than the nonobese of developing incontinence after only one year of the Burch surgery ${ }^{21}$. That is why surgeons began to opt for other techniques, such as the sling.

The influence of BMI on the outcome of sling surgeries is still controversial. Some authors found an association between higher BMI and worse outcomes $^{22}$, while others found no such association ${ }^{23.24}$. A study conducted with 171 women who underwent transobturator sling found a significant reduction in the objective success rate in patients with BMI $>30$ $\mathrm{kg} / \mathrm{m} 2(95.5 \% \text { vs. } 76.3 \%, \mathrm{p}=0.001)^{23}$. On the other hand, another study in which 69 women underwent transobturator sling surgery and 120 underwent retropubic sling found no association between obesity and the surgical outcomes ${ }^{24}$. Similarly, the present study found no association between higher BMI and worse prognosis after surgery, since the cure or improvement rates were similar in the two groups (83.3\% vs. $78.4 \%$ patients with obesity and with normal BMI or overweight, respectively).

It is believed that one of the main etiologies of UI is vaginal delivery, with increased risk with multiparity ${ }^{11}$. A neurophysiological study of the pelvic floor showed that during vaginal delivery, there are imperceptible tears and strains in muscles, ligaments, and nerves responsible for controlling the emptying of the bladder, which lead to $\mathrm{UI}^{25}$. But pregnancy alone is associated to a higher risk of UI, and there are publications that found a positive correlation between parity and the number of pregnancies and the onset of UI, irrespective of the type of delivery ${ }^{26}$. However, until now, no study has demonstrated the relationship of parity and worse prognosis of TOT sling surgery for UI. In our sample, there was a positive correlation between greater parity and worse surgical prognosis. The cure or improvement rate for patients who presented parity equal to or fewer than 4 was $93.8 \%$, while for those that had parity above 4 it was $59 \%(p=0.004)$.

Despite the few data in the literature for comparison, the present study suggests a demographic finding that possibly has a negative influence on the surgical success of SUI corrections, namely the number of births. The other parameters studied showed no significant influence on the surgical outcomes, but it is im- portant to consider that our sample was reduced due to, among other reasons, the limited number of slings we have every month. In relation to BMI, possibly, we could not find any kind of correlation with therapeutic failure because the number of patients with this parameter within the normality was small, only nine women, i.e., $15.8 \%$ of the sample, so our sample population was predominantly pre-obese and obese. The small sample size may also have caused the inclusion of a majority of patients in post-menopause and, for this reason, the influence of estrogen on the surgical outcomes may not have appeared in this population.

The sample used in our study can also be a limiting factor in the interpretation of the data, since the selection of patients was made by convenience, based on the cases operated by the service. This population did not present a normal distribution, and the surgical outcomes were evaluated over a short period of postoperative follow up. Moreover, we did not find a questionnaire or an objective way to classify the surgical outcomes, so the data were dependent on the subjective analysis of the patients operated.

It was not the objective of this study to evaluate the sample patients' data of urodynamic studies or physical examinations, since the indication of surgical treatment for SUI was established regardless of other pelvic floor dysfunctions, if the patient presented a specific complaint of SUI, for which a urodynamic study is indispensable or free from criticism for the diagnosis. However, all the patients who attended the surgical service of the Pelvic Floor Department of the Jundiaí Medical Faculty underwent a physical examination, type I urine, culture and antibiogram testing, and women forwarded to surgery underwent urodynamic testing. Another relevant fact was that the surgical technique for the placement of the transobturator sling was the same in all the cases and performed by the same team of surgeons.

Despite the higher weight tendency and the predominance of post-menopausal patients, the positive results of the transobturator sling technique are compatible with data from the literature, with improvement rates at around $77 \%$, which corroborates the quality of the data.

\section{CONCLUSION}

A number of births greater than four was the only factor associated with a worse surgical outcome for transobturator sling in the population studied. 


\section{RESUMO}

OBJETIVO: O estudo pretende verificar a associação entre fatores de risco relacionados ao surgimento da IUE com resultado do tratamento cirúrgico com sling suburetral transobturador.

PACIENTES E MÉTODOS: Foi realizado estudo retrospectivo com 57 pacientes operadas pelo serviço de Cirurgia do Assoalho Pélvico da FMJ. Foram compilados dados demográficos da amostra, calculado o índice de massa corpórea (IMC) e as pacientes foram divididas de acordo com a resposta ao tratamento cirúrgico.

RESULTADOS: 77,2\% da amostra apresentou-se curada ou melhorada após o tratamento cirúrgico, 75,4\% das mulheres se encontravam na pós-menopausa e 73,7\% negaram tabagismo atual ou passado. A mediana de idade foi de 61 anos, a mediana do número de partos foi de 4,0 e a mediana do IMC foi de 28,6 kg/m2; 50,9\% da amostra foi classificada como pré-obesa. O IMC, o status menopausal, a idade, o tabagismo e a manutenção da atividade sexual não foram fatores associados ao resultado cirúrgico. Porém, a paridade igual ou superior a 5 associou-se a piores resultados pós-operatórios $(p=0,004)$.

CONCLUSÕES: Entre os fatores de risco associados ao surgimento da IUE, apenas a paridade maior que 4 influenciou negativamente as taxas de melhora após cirurgia de sling transobturador.

PALAVRAS-CHAVE: Incontinência urinária. Obesidade. Paridade. Menopausa. Slings suburetrais.

\section{REFERENCES}

1. Manefee SA, Wall LL. Incontinência, prolapso e distúrbios do assoalho pélvico. In: Bereck JS, ed. Novak tratado de ginecologia. 13a ed. Rio de Janeiro: Guanabara Koogan; 2005. p.601-61.

2. Pena Outeiriño |M, Rodríguez Pérez A|, Villodres Duarte A, Mármol Navarro S, Lozano Blasco JM. Tratamiento de la disfunción del suelo pélvico. Actas Urol Esp. 2007;31(7):719-31.

3. Pereira I, Valentim-Lourenço A, Castro C, Martins I, Henriques A, Ribeirinho $\mathrm{AL}$. Incontinence surgery in obese women: comparative analysis of short- and long-term outcomes with a transobturator sling. Int Urogynecol J. 2016;27(2):247-53.

4. Botelho F, Silva C, Cruz F. Incontinência urinária feminina. Acta Urológica. 2007;24(1):79-82.

5. Haddad JM. Tratamento da incontinência urinária. In: Manual de uroginecologia e cirurgia vaginal. São Paulo: Federação Brasileira das Associações de Ginecologia e Obstetrícia (FEBRASGO);2015. p.20-40.

6. Oliveira E, Zuliani LMM, Ishicava I, Silva SV, Albuquerque SSR, Souza AMB, et al. Avaliação dos fatores relacionados à ocorrência da incontinência urinária feminina. Rev Assoc Med Bras. 2010;56(6):688-90

7. Carvalho MP, Andrade FP, Peres W, Martinelli T, Simch F, Orcy RB, et al. O impacto da incontinência urinária e seus fatores associados em idosas. Rev Bras Geriatr Gerontol. 2014;17(4):721-30.

8. Langford CF, Elmissiry MM, Ghoniem GM. Do women have realistic expectations of treatment for stress urinary incontinence? Neurourol Urodyn. 2008;27(6):480-4.

9. Chang $\mathrm{KM}$, Hsieh $\mathrm{CH}$, Chiang HS, Lee TS. Risk factors for urinary incontinence among women aged 60 or over with hypertension in Taiwan. Taiwan J Obstet Gynecol. 2014; 53(2):183-6.

10. Minassian VA, Stewart WF, Wood GC. Urinary incontinence in women: variation in prevalence estimates and risk factors. Obstet Gynecol. 2008;111(2 Pt 1):324-31.

11. Wilson PD, Herbison RM, Herbison GP. Obstetric practice and the prevalence of urinary incontinence three months after delivery. $\mathrm{Br}$ J Obstet Gynaecol. 1996;103(2):154-61.

12. Chung J, Bai SW. Roles of sex steroid receptors and cell cycle regulation in pathogenesis of pelvic organ prolapse. Curr Opin Obstet Gynecol. 2006;18(5):551-4.

13. Matsubara S, Okada H, Shirakawa T, Gotoh A, Kuno T, Kamidono S. Estrogen levels influence beta-3-adrenoceptor-mediated relaxation of the female rat detrusor muscle. Urology. 2002;59(4):621-5.

14. Weber MA, Kleijn MH, Langendam M, Limpens J, Heineman MJ, Roovers
JP. Local oestrogen for pelvic floor disorders: a systematic review. PLoS One. 2015;10(9):e0136265

15. Bodner-Adler B, Bodner K, Kimberger $O$, Halpern K, Rieken M, Koelbl H, et al. Role of serum steroid hormones in women with stress urinary incontinence: a case-control study. BJU Int. 2017;120(3):416-21.

16. Saadia Z. Effect of age, educational status, parity and BMI on development of urinary incontinence: a cross sectional study in Saudi population. Mater Sociomed. 2015;27(4):251-4.

17. Alling Møller L, Lose G, Jørgensen T. Risk factors of lower urinary tract symptoms in women 40 to 60 years of age. Obstet Gynecol. 2000;96(3):446-51.

18. O'Boyle C), O'Sullivan OE, Shabana H, Boyce M, O'Reilly BA. The effect of bariatric surgery on urinary incontinence in women. Obes Surg. 2016;26(7):1471-8.

19. Bent AE. Uroginecologia e disfunção do assoalho pélvico. In: Bereck JK, ed. Novak tratado de ginecologia. $5^{a}$ ed. Rio de Janeiro: Guanabara Koogan; 2006. p.444.

20. Bolwerk A, Ferreira RG. Sling transobturatório no tratamento da incontinência urinária: revisão de literatura [cited 2017 Jun 26]. Available from: http:// www.cpgls.pucgoias.edu.br/6mostra/artigos/SAUDE/ALO\%C3\%8DSIO\%20BOLWERK\%20E\%20RUI\%20GILBERTO\%20FERREIRA.pdf

21. Viecelli CF, Santos DCS, Aguiar WWS, Martins-Costa SH, Corleta HE, Ramos JGL. Obesidade como fator de risco para a falha da cirurgia de Burch. Rev Bras Ginecol Obstet. 2009;31(4):182-8.

22. Toledo LGM. Fatores preditivos de insucesso do sling transobturatório no tratamento da incontinência urinária de esforço em mulheres [Tese de doutorado]. São Paulo: Faculdade de Ciências Médicas da Santa Casa de São Paulo; 2012.

23. Kokanali MK, Cavkaytar S, Kokanali D, Aksakal O, Doganay M. A comparative study for short-term surgical outcomes of midurethral sling procedures in obese and non-obese women with stress urinary incontinence. J Obstet Gynaecol. 2016;36(8):1080-5.

24. Haverkorn RM, Williams BJ, Kubricht WS $3^{\text {rd }}$, Gomelsky A. Is obesity a risk factor for failure and complications after surgery for incontinence and prolapse in women? J Urol. 2011;185(3):987-92.

25. Allen RE, Hosker GL, Smith AR, Warrell DW. Pelvic floor damage and childbirth: a neurophysiological study. Br J Obstet Gynaecol. 1990;97(9):770-9.

26. Dellú $M C$, Zácaro $P M D$, Schmitt $A C B$. Prevalência de sintomas urinários e fatores obstétricos associados em mulheres adultas. Rev Bras Fisioter. 2008;12(6). [cited 2019 lan 26]. Available from: http://www.scielo.br/pdf/ rbfis/v12n6/aop005.pdf 